\title{
Resistin enhances the expansion of regulatory $T$ cells through modulation of dendritic cells
}

\author{
Young Min Son'1, Sung Min Ahn'1, Gi Rak Kim¹, Yang Soo Moon², Sang Hoon Kim³, Yeong-Min Park', Woon Kyu Lee, \\ Tae Sun Min6, Seung Hyun Han and Cheol-Heui Yun*1
}

\begin{abstract}
Background: Resistin, a member of adipokine family, is known to be involved in the modulation of immune responses including inflammatory activity. Interestingly, resistin is secreted by adipocytes in mice and rats whereas it is secreted by leukocytes in humans. However, the mechanism behind the effect of resistin on the expansion of regulatory $T$ cells (Tregs) remains poorly understood. Therefore, we examined regulatory effect of resistin on the induction and cellular modification of Tregs.

Results: Both protein and mRNA expression of FoxP3, a representative marker of Tregs, increased in a dose-dependent manner when peripheral blood mononuclear cells were treated with resistin. At the same time, resistin had no direct effect on the induction of FoxP3 in CD4+ T cells, suggesting an indirect role through other cells type(s). Since DCs are an important player in the differentiation of T cells, we focused on the role of DCs in the modulation of Tregs by resistin. Resistin suppressed the expression of interferon regulatory factor (IRF)- 1 and its target cytokines, IL-6, IL-23p19 and IL$12 \mathrm{p} 40$, in DCs. Furthermore, FoxP3 expression is increased in CD4+T cells when co-cultured with DCs and concomitantly treated with resistin.
\end{abstract}

Conclusion: Our results suggest that resistin induces expansion of functional Tregs only when co-cultured with DCs.

\section{Background}

Resistin, a novel adipocyte-secreted hormone, has gained attention for its involvement in insulin resistance in obesity and diabetes mellitus [1]. In murine animals, resistin is secreted from mature white adipocytes and decreases insulin sensitivity, whereas in humans it is mainly secreted from immune cells such as macrophages and monocytes and organs such as the spleen and bone marrow [2]. Recently, several groups have reported a close relationship between resistin and inflammation. Resistin increases the production of pro-inflammatory cytokines tumor necrosis factor- $\alpha$ (TNF- $\alpha$ ) and interleukin (IL)-12, both of which are important for $\mathrm{T}$ cell development, through the regulation of NF- $\mathrm{KB}$ signaling pathway in human macrophages [3]. In the clinical setting, high lev-

\footnotetext{
* Correspondence: cyun@snu.ac.kr

1 Protein Engineering and Comparative Immunology, Department of Agricultural Biotechnology and Research Institute for Agriculture and Life Sciences, Seoul National University, 599 Gwanak-ro, Gwanak-gu, Seoul 151-921, Republic of Korea

Full list of author information is available at the end of the article
}

els of resistin expression are present in patients with rheumatoid arthritis [3].

Forkhead box P3 (FoxP3), a key regulator of the development of regulatory $\mathrm{T}$ cells (Tregs, $\mathrm{CD} 4{ }^{+} \mathrm{CD} 25^{+}$FoxP3 ${ }^{+}$ $\mathrm{T}$ cells), is a hallmark of Tregs [4], which exhibit a suppressive response to the effector function of $\mathrm{CD} 4+\mathrm{T}$ cells [5]. Two types of Tregs have been reported: natural Tregs (nTregs), which naturally occur in the thymus, and inducible Tregs (iTregs), which can be induced from naïve $\mathrm{T}$ cells. The iTregs exhibit less suppressive function to effector T cell responses than nTregs [6]. Interleukin (IL)2 , transforming growth factor- $\beta$ (TGF- $\beta$ ) and ligands for the activation of $\mathrm{T}$ cell receptors (i.e., anti-CD2, -CD3 and -CD28) have been reported as important factors in the induction of Tregs from naïve T cells [7].

Dendritic cells (DCs) play a vital role in the modulation and activation of $\mathrm{T}$ cells, not only for the delivery and presentation of antigenic determinant(s) to $\mathrm{T}$ cells, but also in the induction of differentiation of naïve $\mathrm{T}$ cells into $\mathrm{T}$ cells subtypes via cytokine secretion and/or cellto-cell contact [8]. Recently, several studies have reported 
that DCs are closely involved in the differentiation of Tregs. For example, DCs either secreting TGF- $\beta$ or in the presence of TGF- $\beta$ induce differentiation of CD4 ${ }^{+} \mathrm{CD} 25+{ }^{+}$oxP3 ${ }^{+}$Tregs [9]. Interferon regulatory factor-1 (IRF-1) $1 /$ DCs enhance the suppressive ability of Tregs and cause tolerogenic features via induction of Tregs due to the fact that the IRF-1/- DCs secrete more IL-10 and TGF- $\beta$ but less IL-6, IL-12p40 and IFN- $\gamma$ than wild type DCs [10].

We previously reported that resistin impairs the ability of human monocyte-derived DCs to uptake antigens and produce cytokines (IL-12p40, IL-6 and TNF- $\alpha$ ). These impaired DCs negatively regulate $\mathrm{T}$ cell responses such as proliferation of and differentiation into Th1 cells [11]. In the current study, we further examine the ability of DCs treated with resistin to induce expansion of Tregs.

\section{Methods \\ Reagents}

Human recombinant resistin, endotoxin level less than $0.1 \mathrm{ng} / \mu \mathrm{g}$, was purchased from Peprotech (Rocky Hill, $\mathrm{NJ})$. To provide the effects of irrelevant control, we transformed recombinant resistin to heat-inactivated resistin through incubation with $100^{\circ} \mathrm{C}$ for $10 \mathrm{~min}$. RPMI-1640 Glutamax medium, fetal bovine serum (FBS) and antibiotics $(100 \mathrm{U} / \mathrm{ml}$ penicillin and $100 \mu \mathrm{g} / \mathrm{ml}$ streptomycin) were purchased from Invitrogen (Grand Island, NY).

\section{Preparation of human monocyte-derived DCs and $\mathrm{CD}^{+}{ }^{+} \mathrm{T}$ cells}

PBMCs were isolated by density gradient centrifugation (420 $\times g$ for $25 \mathrm{~min}$ without brake) using Ficoll-Paque Plus (Amersham Bioscience, Buckinghamshire, UK). All experiments involving human blood were approved by the Institutional Review Board of Seoul National University (IRB no. 0705/001-002). CD14+ monocytes or CD4+ $\mathrm{T}$ cells (purity $>95 \%$ ) were isolated from PBMCs using magnetic bead-based positive selection with a kit (BD Biosciences, San Diego, CA). CD14+ monocytes were suspended in complete media consisting of RPMI-1640 Glutamax medium supplemented with $10 \% \mathrm{FBS}$ and $1 \mathrm{mM}$ sodium pyruvate, $100 \mathrm{U} / \mathrm{ml}$ penicillin and $100 \mu \mathrm{g} / \mathrm{ml}$ streptomycin. To generate immature DCs, isolated CD14+ monocytes were cultured with $500 \mathrm{U} / \mathrm{ml}$ of hrIL-4 and $800 \mathrm{U} / \mathrm{ml}$ of hrGM-CSF (both from R \& D Systems, Minneapolis, MN) for 6 days with a change of media every 3 days.

\section{RNA isolation and reverse transcriptase-polymerase chain reaction (RT-PCR)}

Cells were lysed with $1 \mathrm{ml}$ of Trizol (Invitrogen) and 200 $\mu \mathrm{l}$ of chloroform was added. The tubes were shaken gently and incubated for $5 \mathrm{~min}$ at room temperature. The tubes were centrifuged at $12,000 \times g$ for $17 \mathrm{~min}$ and the aqueous phase containing RNA was transferred into a new tube. After transfer, $0.5 \mathrm{ml}$ of isopropanol was added to the RNA solution, mixed by gentle inversion, and then incubated for $10 \mathrm{~min}$ at room temperature. The suspended RNA was precipitated by centrifugation at 12,000 $\times g$ for $12 \mathrm{~min}$. The supernatant was discarded and the RNA pellet was washed with $75 \%$ ethanol followed by centrifugation at $7500 \times g$ for $7 \mathrm{~min}$. The supernatant was discarded and the RNA pellet was re-suspended in nuclease-free water.

Isolated total RNA was reverse-transcribed into cDNA with oligo-dT primers (Promega, San Luis Obispo, CA). The cDNA was amplified by PCR in a total volume of 10 $\mu \mathrm{l}$ containing 0.5 units of Taq polymerase and two picomoles of specific primers for human FoxP3, TGF- $\beta$, IRF1, IL-12p40, IL-6, IL-10, CTLA-4 or $\beta$-actin (Table 1). PCR was performed in a thermal cycler (Bio-Rad Laboratories, Hercules, CA) with pre-denaturation at $94^{\circ} \mathrm{C}$ for 5 min, followed by 28 cycles of denaturation at $94^{\circ} \mathrm{C}$ for 30 $\mathrm{sec}$, annealing at the appropriate annealing temperature (Table 1) for $30 \mathrm{sec}$ and extension at $72^{\circ} \mathrm{C}$ for $1 \mathrm{~min}$, and finished with an additional elongation step for $7 \mathrm{~min}$ at $72^{\circ} \mathrm{C}$. Amplified PCR products were separated by electrophoresis using a $2 \%$ agarose gel containing $1 \mu \mathrm{g} / \mathrm{ml}$ ethidium bromide. To quantitate the expression of each mRNA, the ratio of each mRNA to $\beta$-actin was measured using Multi-gauge software (Fujifilm, Tokyo, Japan).

\section{IRF-1 detection by Western blot analysis}

$5 \times 10^{5}$ cells of DCs incubated with $500 \mathrm{ng} / \mathrm{ml}$ of resistin for different time periods $(0,1,6,12$ and $24 \mathrm{hrs})$ in 24well plate (Nalgene Nunc International, Rochester, NY) were washed with cold phosphate buffered saline (PBS) and then lysed in RIPA lysis buffer containing $150 \mathrm{mM}$ $\mathrm{NaCl}, 1 \% \mathrm{NP}-40,0.5 \%$ deoxycholate, $0.1 \%$ SDS, $50 \mathrm{mM}$ Tris pH7.4, protease inhibitor cocktail (Roche, Mannheim, Germany), $2 \mathrm{mM} \mathrm{NaF}, 0.1 \mathrm{mM}$ sodium orthovanadate and $2 \mathrm{mM}$ glycerol phosphate. After centrifugation at $28,000 \times g$ for $7 \mathrm{~min}$ at $4^{\circ} \mathrm{C}$, the supernatant was transferred to a new tube and the concentration of protein was determined by Bradford assay (Bio-Rad Laboratories) with bovine serum albumin (BSA) as a standard. Twentyfive micrograms of proteins were separated by $12 \%$ SDSpolyacrylamide gel electrophoresis and transferred to a polyvinylidene difluoride membrane (Amersham Bioscience). The membrane was blocked with 5\% non-fat milk containing Tris-buffered saline Tween-20 (TBST; $0.1 \mathrm{M}$ Tris, $0.9 \% \mathrm{NaCl}$, and $0.1 \%$ Tween 20 ) overnight at $4{ }^{\circ} \mathrm{C}$. After washing three times with TBST, the membrane was incubated with rabbit anti-human IRF-1 antibody (Santa Cruz Biotechnology, Inc) for $3 \mathrm{hrs}$ at room temperature and washed with TBST three times. Protein bands were detected using mouse anti-rabbit IgG conjugated with horseradish peroxidase (Chemicon, Temecula, CA) and 
Table 1: The primers used in the present study for RT-PCR

\begin{tabular}{|c|c|c|c|c|}
\hline Primer & Sequences & $\begin{array}{l}\text { AT* }^{*} \\
\left({ }^{\circ} \mathrm{C}\right)\end{array}$ & $\begin{array}{l}\text { Product size } \\
\text { (bp) }\end{array}$ & NCBI numbers \\
\hline \multirow[t]{2}{*}{ FoxP3 } & forward: 5'-AGT TCC TCC ACA ACA TGG AC-3' & 57 & 219 & NM_014009 \\
\hline & reverse: 5'-CAA AGC ACT TGT GCA GAC TC-3' & & & \\
\hline \multirow[t]{2}{*}{ TGF- $\beta$} & forward: 5'-AAA GAC TTा TCC CCA GAC CT -3' & 58 & 155 & NM_000660 \\
\hline & reverse: 5'-AAG GTG GGT GGT CTT GAA TA -3' & & & \\
\hline \multirow[t]{2}{*}{ IRF-1 } & forward: 5'-GTG AAA GAC CAG AGC AGG-3' & 57 & 400 & NM_002198 \\
\hline & reverse: 5'-CTG TTG TAG CTT CAG AGG-3' & & & \\
\hline \multirow[t]{2}{*}{ IL-12p40 } & forward: 5'- GGA CCA GAG CAG TGA GGT CTT-3' & 57 & 209 & AF180563 \\
\hline & reverse: 5'-CTC CTT GTT GTC CCC TCT GA-3' & & & \\
\hline \multirow[t]{2}{*}{ IL-6 } & forward: 5'- TAG CCG CCC CAC ACA GAC AG-3' & 61 & 408 & NM_000600 \\
\hline & reverse: 5'-GGC TGG CAT TTG TGG TTG GG-3' & & & \\
\hline \multirow[t]{2}{*}{ IL-10 } & forward: 5'- AGA AAG GCA TCT ACA AAG CCA-3' & 58 & 239 & NM_000572 \\
\hline & reverse: 5'-TGG GGG TTG AGG TAT CAG AG-3' & & & \\
\hline \multirow[t]{2}{*}{ CTLA-4 } & forward: 5'- AGT TाT GTG GAG GAG CTC AG-3' & 57 & 247 & AF414120 \\
\hline & reverse: 5'-CTC CTG GAG TAA GCC ATT GT-3' & & & \\
\hline \multirow[t]{2}{*}{$\beta$-actin } & forward: 5'- GGA CTT CGA GCA AGA GAT GG-3' & 55 & 234 & NM_001101 \\
\hline & reverse: 5'-AGC ACT GTG TTG GCG TAC AG-3' & & & \\
\hline
\end{tabular}

${ }^{*} \mathrm{AT}$, annealing temperature

developed by the enhanced chemiluminescence system (GE Healthcare, Buckinghamshire, UK).

\section{TGF- $\beta$ detection by enzyme-linked immunosorbent assay} (ELISA)

CD4 ${ }^{+} \mathrm{T}$ cells and DCs $\left(2 \times 10^{5}\right.$ cells each $)$ were co-cultured with or without $0.5 \mu \mathrm{g} / \mathrm{ml}$ of resistin for 4 days. Antihuman CD2 and CD3 antibodies $(0.1 \mu \mathrm{g} / \mathrm{ml}$ each) (Miltenyi Biotec, Auburn, CA) were then added and the cultures were incubated for 3 more days. The concentration of human TGF- $\beta$ in the supernatant was measured using an ELISA DuoSet kit (R \& D Systems). Briefly, TGF- $\beta$ capture antibody was coated on each well of a 96-well plate (Nalgene Nunc International) and incubated overnight at $4^{\circ} \mathrm{C}$. The wells were blocked with blocking buffer (0.1\% BSA in PBS) for $1 \mathrm{hr}$. After oxidation-reduction of the supernatant to activate TGF- $\beta$, the supernatants from the culture or standard samples were added and incubated for 2 hrs at room temperature. Next, detection antibody conjugated with biotin was added to each well and incubated for $2 \mathrm{hrs}$ at room temperature. The plates were washed three times with washing buffer $(0.05 \%$ Tween 20 in PBS) between each step. The specific reaction was detected using streptavidin-HRP followed by TMB in the substrate buffer (Sigma-Aldrich Co., Saint Louis, MO). The reaction was stopped with $2 \mathrm{NH}_{2} \mathrm{SO}_{4}$ and the amount of TGF- $\beta$ was measured by microplate reader (Molecular Devices, Sunnyvale, CA).

\section{Flow cytometric analysis}

Cells cultured under different conditions were harvested and washed three times with cold PBS. The cells were stained with the desired combination of anti-human CD25-APC and FoxP3-PE antibodies (BD biosciences) for $20 \mathrm{~min}$ at $4{ }^{\circ} \mathrm{C}$ in the dark. The cells were washed and changes in marker expression were measured using a FACSCalibur with Cell-Quest software (BD Biosciences). All flow cytometric data were analyzed with FlowJo software (Tree Star, San Carlos, CA).

To evaluate the effect of TGF- $\beta$ on the induction of Tregs, CD4+ $\mathrm{T}$ cells co-cultured with $\mathrm{DCs}$ were pretreated for $1 \mathrm{hr}$ TGF- $\beta$ receptor I inhibitor (Calbiochem, San Diego, CA). After pre-treatment, the cells were incubated with or without resistin $(0.5 \mu \mathrm{g} / \mathrm{ml})$ for 4 days and then anti-human CD2 and CD3 antibodies were added and the cultures were incubated for an additional 3 days. After staining the cells with anti-human CD25-APC and FoxP3-PE antibodies, CD25+ FoxP3+ Tregs were detected using flow cytometry as described above.

\section{Suppression activity of Tregs against $\mathrm{CD} 4+\mathrm{CD} 25-\mathrm{T}$ cells}

$\mathrm{CD}^{+} \mathrm{T}$ cells and DCs were co-cultured with or without $0.5 \mu \mathrm{g} / \mathrm{ml}$ of resistin for 4 days and then anti-human CD2 and CD3 antibodies (Miltenyi Biotec) were added and the cultures were incubated for 3 more days. After washing with cold PBS, the cells were stained with anti-human CD25-APC antibody for $20 \mathrm{~min}$ at $4^{\circ} \mathrm{C}$ in the dark and 
then washed with cold PBS. CD25+ $\mathrm{T}$ (e.g., CD4 ${ }^{+} \mathrm{CD} 25^{+}$) effector cells (purity > 97\%) were isolated using anti-APC particles (BD biosciences) together with $\mathrm{IMag}^{\mathrm{Tm}}$, a magnetic bead-based positive selection kit (BD biosciences). $\mathrm{CD}^{+} \mathrm{CD} 25^{-} \mathrm{T}$ cells (purity $>95 \%$ ) were isolated using a regulatory $\mathrm{T}$ cell isolation kit (Miltenyi Biotec), labeled with $2.5 \mu \mathrm{M}$ of CFSE (Invitrogen) for $8 \mathrm{~min}$ in $37^{\circ} \mathrm{C}$ and used as target cells. Effector cells $\left(2 \times 10^{5}\right.$ cells $)$ and an equal number of target cells were co-cultured with antihuman CD2 and CD3 antibodies (Miltenyi Biotec) for an additional 5 days in a 24-wells plate. The intensity of CFSE in the target cells was measured using a FACSCalibur with CellQuest (BD Biosciences). All flow cytometric data were analyzed by FlowJo software (Tree Star).

\section{Statistical analysis}

Comparative data were analyzed using Student's $t$-test and considered statistically significant when the $P$ value was less than 0.05 .

\section{Results \\ Resistin induces expression of FoxP3 in PBMC, but not in CD4 + T cells}

To examine whether resistin could modulate the induction of Tregs, we tested the expression level of FoxP3 in PBMCs and CD4+ $\mathrm{T}$ cells. FoxP3 is one of the most representative markers of Tregs, together with CTLA4, TGF- $\beta$ and IL-10 [6]. Since FoxP3 is expressed in T cells only, PBMCs and $\mathrm{CD}^{+}{ }^{+} \mathrm{T}$ cells were incubated with $0,50,100$, 200 or $500 \mathrm{ng} / \mathrm{ml}$ of resistin for $6 \mathrm{hrs}$. The expression level of FoxP3 was then measured by RT-PCR. The expression of FoxP3 increased significantly $(P<0.05)$ in a dose-dependent manner in PBMCs treated with resistin (figure $1 \mathrm{~A}$ and $1 \mathrm{C}$ ). Minimal, if any, change was found in the expression of TGF- $\beta$ (figure 1A). It is to note that the expression level of FoxP3 and TGF- $\beta$ was, unexpectedly, not changed in $\mathrm{CD} 4{ }^{+} \mathrm{T}$ cells treated with any concentration of resistin (figure 1B and $1 \mathrm{C}$ ). These results suggest that the resistin-induced expression of FoxP3 in Tregs is mediated by indirect where $\mathrm{CD} 4{ }^{+}$cells are not necessarily required.

\section{Resistin-treated DCs enhance the expansion of Tregs}

The primary role of DCs is to interact with T cells and trigger adaptive immune responses, but DCs are also involved in the differentiation of Tregs [12]. Therefore, to further examine whether resistin-treated DCs are involved in the regulation of Tregs, CD4 ${ }^{+} \mathrm{T}$ cells and DCs were co-cultured and concomitantly treated with resistin. mRNA expression levels of TGF- $\beta$, CTLA-4 and FoxP3, representative markers of Tregs, were subsequently measured. The expression of TGF- $\beta, C T L A-4$ and FoxP3 was greater in cells treated with resistin than those without resistin treatment (figure 2A). This finding was further confirmed by changes of $\mathrm{CD} 4+\mathrm{CD} 25+\mathrm{FoxP} 3+$ Tregs using flow cytometry. As shown in figure $2 \mathrm{~B}$ (upper panel), $\mathrm{CD}^{+}{ }^{+} \mathrm{CD} 25^{+} \mathrm{FoxP}^{+}$cells were significantly $(P<0.05)$ higher in cells treated with resistin than those without treatment (additional file 1). And, to confirm whether the increased number of Tregs were induced from naïve $\mathrm{CD}^{+} \mathrm{T}$ cells or expanded from Tregs, $\mathrm{CD} 4{ }^{+} \mathrm{CD} 25^{-}$naïve $\mathrm{T}$ cells were co-cultured and concomitantly treated with resistin. The result showed that $\mathrm{CD} 25^{+} \mathrm{FoxP} 3^{+}$Tregs were expanded from Tregs but were merely induced from $\mathrm{CD} 4{ }^{+} \mathrm{CD} 25-$ naïve $\mathrm{T}$ cells when co-cultured with resistintreated DCs (figure 2B bottom panel). Finally, CD4+ $\mathrm{CD} 25^{+} \mathrm{T}$ cells were isolated after co-culture of $\mathrm{T}$ cells and DCs concomitantly treated with/without resistin in order to examine their functional capacity to suppress the activity of effector $\mathrm{T}$ cells. CD4+ CD25- T cells labeled with CFSE were co-cultured with $\mathrm{CD} 4{ }^{+} \mathrm{CD} 25^{+} \mathrm{T}$ cells and stimulated with anti-human CD2 and CD3 antibodies. When compared with a proliferation of CD4+ CD25naïve $\mathrm{T}$ cells only, the $\mathrm{CD} 4{ }^{+} \mathrm{CD} 25^{+}$Tregs induced by $\mathrm{DCs}$ treated with resistin suppressed the proliferation of $\mathrm{CD} 4^{+}$ CD25- naïve $\mathrm{T}$ cells similar to $\mathrm{CD} 4^{+} \mathrm{CD} 25^{+} \mathrm{T}$ cells induced by $\mathrm{DCs}$ without resistin (figure 2C). These results suggest that resistin modulates the functionality of DCs to enhance the expansion of CD4 ${ }^{+} \mathrm{CD} 25^{+} \mathrm{FoxP}^{+}$ Tregs.

\section{The effects of resistin in DCs for expansion of Tregs}

Next, we examined the change of IRF-1 and cytokines, IL-12p40, IL-23p19, IL-6, IL-10 and TGF- $\beta$ in relation to the differentiation of T cells. IRF-1 both, at mRNA (figure $3 \mathrm{~A}$ ) and protein level (figure $3 \mathrm{~B}$ ) was suppressed in a time- and dose-dependent manner when DCs were treated with resistin. Note that heat-inactivated resistin was used. It has been previously shown that the expression of inflammatory cytokines, TNF- $\alpha, I F N-\gamma, I L-12 p 40$ and $I L-15$, was significantly reduced while the expression of tolerogenic cytokines, $I L-10$ and TGF- $\beta$, was increased in DCs from IRF-1- mice [10]. IL-12, IL-23 and IL-6 are known to be involved in the differentiation of naive $\mathrm{T}$ cells into Th1 and Th17 subtypes, respectively, while IL10 and TGF- $\beta$ induce the differentiation of Tr1 and Th3 subtypes, respectively [13]. Accordingly, we further examined the expression of $I L-12 p 40, I L-23 p 19, I L-6, I L-$ 10 and TGF- $\beta$ in DCs after resistin treatment. The expression of $I L-12 p 40, I L-23 p 19$ and $I L-6$ decreased in DCs treated with resistin, while no significant differences were observed in the expression of $I L-10$ and TGF- $\beta$ (figure $3 \mathrm{C}$ ). And through the PI/annexin V, CD40, CD80, CD86 and MHC class II staining, we confirmed that resistin is involved in the process of neither apoptosis nor maturation of DCs (data not shown). These results suggest that resistin suppresses the expression of $I L-12 p 40$, 


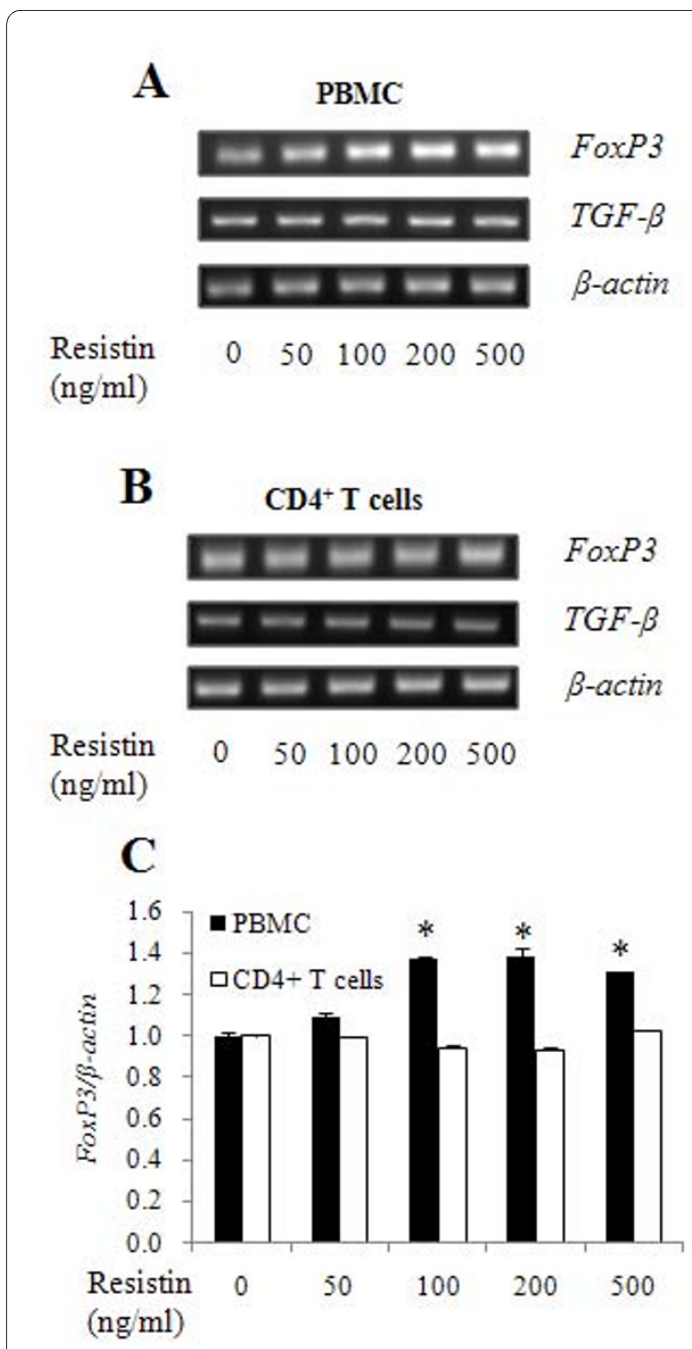

Figure 1 Expression of FoxP3 mRNA in PBMCs or CD4 ${ }^{+} \mathrm{T}$ cells treated with resistin. (A) PBMC and (B) $C D 4^{+} T$ cells isolated from human adult peripheral blood were treated with various concentrations of resistin $(0,50,100,200$ or $500 \mathrm{ng} / \mathrm{ml})$ for 6 hrs. For measurement of FoxP3 and TGF- $\beta$ mRNA expression, RT-PCR was performed as described in Materials and Methods. (C) The intensities of the FoxP3 were normalized to $\beta$-actin. Results are representative of three separate experiments with similar results.

$I L-23 p 19$ and $I L-6$ through the regulation of IRF- 1 induction in DCs.

\section{Tregs were induced by TGF- $\beta$ secreted by themselves but not by DCs treated with resistin}

To investigate whether TGF- $\beta$ secreted from DCs is involved in the induction of Tregs, $\mathrm{CD} 4{ }^{+} \mathrm{T}$ cells were pretreated with TGF- $\beta$ receptor inhibitor, co-cultured with DCs, and concomitantly treated with resistin. Tregs were induced when the cells were treated with resistin as expected, but treatment with TGF- $\beta$ receptor inhibitor suppressed such induction (figure 4A). We also examined the level of TGF- $\beta$ in the culture supernatant. TGF- $\beta$ increased in $\mathrm{CD} 44^{+} \mathrm{T}$ cells when co-cultured with $\mathrm{DCs}$ and treated with resistin (figure 4B). The expression of TGF- $\beta$ mRNA was not significantly different in DCs alone treated with resistin (figure $4 \mathrm{C}$ ). These results suggest that TGF- $\beta$ produced from $C D 4^{+} \mathrm{T}$ cells co-cultured with DCs together with resistin treatment, was the major source to induce the differentiation of Tregs, rather than TGF- $\beta$ secreted from DCs.

\section{Discussion}

The major findings of this study are as follow: (i) Resistin indirectly induced the expression of FoxP3 in PBMCs, (ii) Resistin suppressed the expression of IRF-1, IL-6, IL12p40 and IL-23p19 in DCs, (iii) DCs treated with resistin enhanced the expansion of $\mathrm{CD} 44^{+} \mathrm{CD}_{25} 5^{+} \mathrm{FoxP}^{+} \mathrm{T}$ cells, (iv) TGF- $\beta$ caused the expansion of Tregs and (v) TGF- $\beta$ was mainly produced from Tregs during the coculture of $\mathrm{T}$ cells and DCs together with resistin treatment.

Resistin was originally described because of its promotion of resistance against the insulin response [1] and adipogenesis in fat tissue [14]. More recently, important roles of resistin in the human immune response [15] and inflammation, including induction of pro-inflammatory cytokines, $[2,3,16]$ have been reported. In the previous study, we reported the immunomodulatory effect of resistin on human DCs for the first time [11]. We have demonstrated that resistin impairs not only the ability of antigen-uptake and cytokine production in DCs, but also the proliferation and differentiation of $\mathrm{T}$ cells. These results suggest that the DCs treated with resistin may negatively regulate the effector function of $\mathrm{T}$ cells. Our findings are in agreement with those of Rutella et al., who also reported that tolerogenic DCs, known to express high amounts of IL-10 but not IL-12 in the immature state, induce Tregs [17]. It is to note that Tregs are well known for their role in suppressing a variety of $\mathrm{T}$ cell responses. Tregs also regulate DCs and NK cells by suppressing expression of the CCR5 ligand and IL-15R $\alpha$, respectively [18]. Accordingly, we hypothesized that resistin could be involved in the expansion of Tregs through the regulation of DCs.

In order to clarify whether resistin could induce the expansion of Tregs, we treated PBMCs and purified CD4 ${ }^{+}$ $\mathrm{T}$ cells with resistin and analyzed the changes in FoxP3 expression. Resistin had no direct effect on the induction of FoxP3 mRNA expression in CD4+ $\mathrm{T}$ cells, but did increase FoxP3 mRNA in PBMCs. This result suggests that resistin may indirectly induce Tregs through the regulation of other cell types, most likely DCs. Tregs can be induced by cell-to-cell contact, for instance, DCs and T cells. DCs, producing TGF- $\beta$, IL-10 and indoleamine 2,3dioxygenase can induce the differentiation of Tregs in vitro and in vivo [12]. Since immature DCs have a better 
A

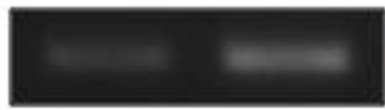

\section{CTLA-4}

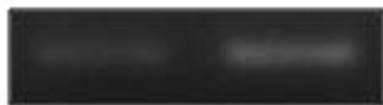

FoxP3

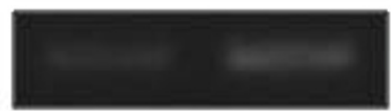

$T G F-\beta$

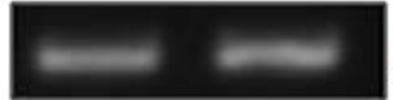

$\beta$-actin

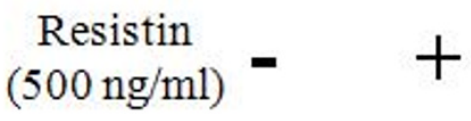

C

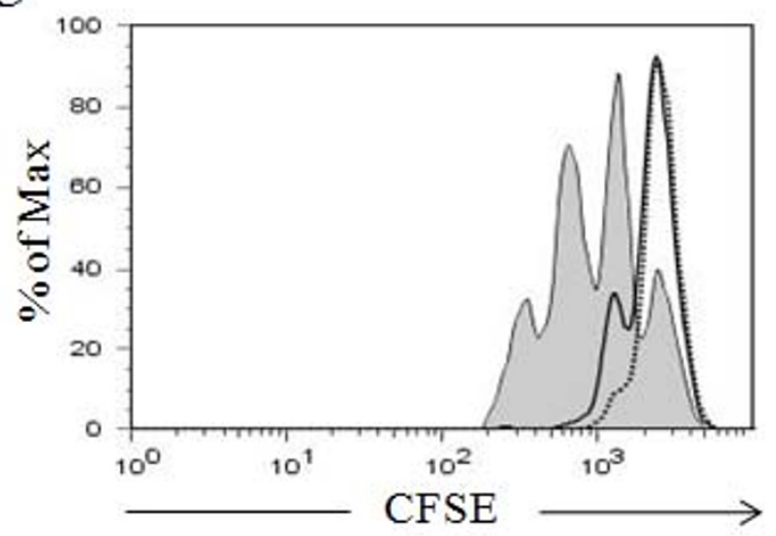

B
Resistin
$(\mathrm{ng} / \mathrm{ml})$
50
100
$\mathrm{CD}^{+} \mathrm{T}$ cells $+\mathrm{DCs}$
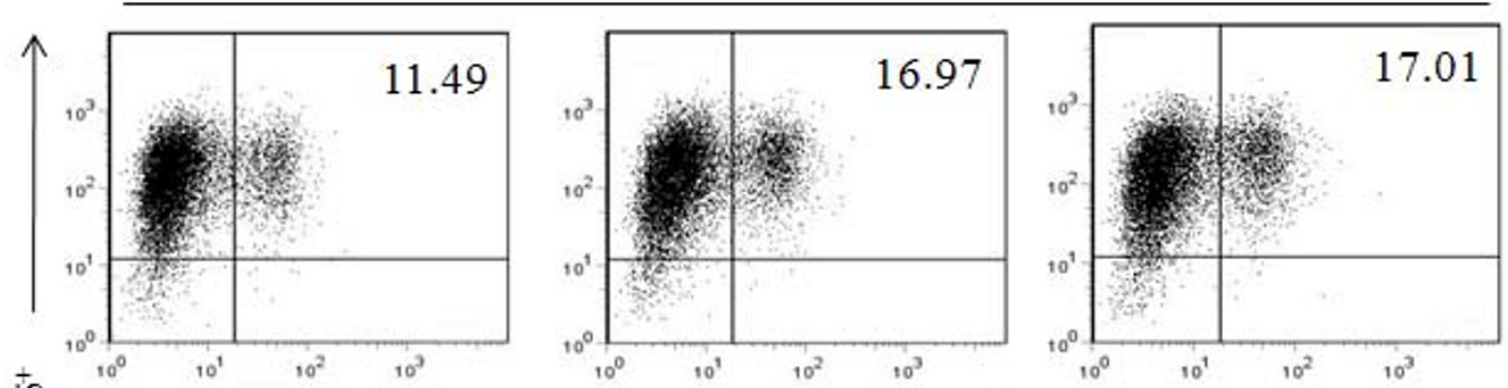

in

$\mathrm{CD} 4^{+} \mathrm{CD} 25^{-} \mathrm{T}$ cells $+\mathrm{DCs}$
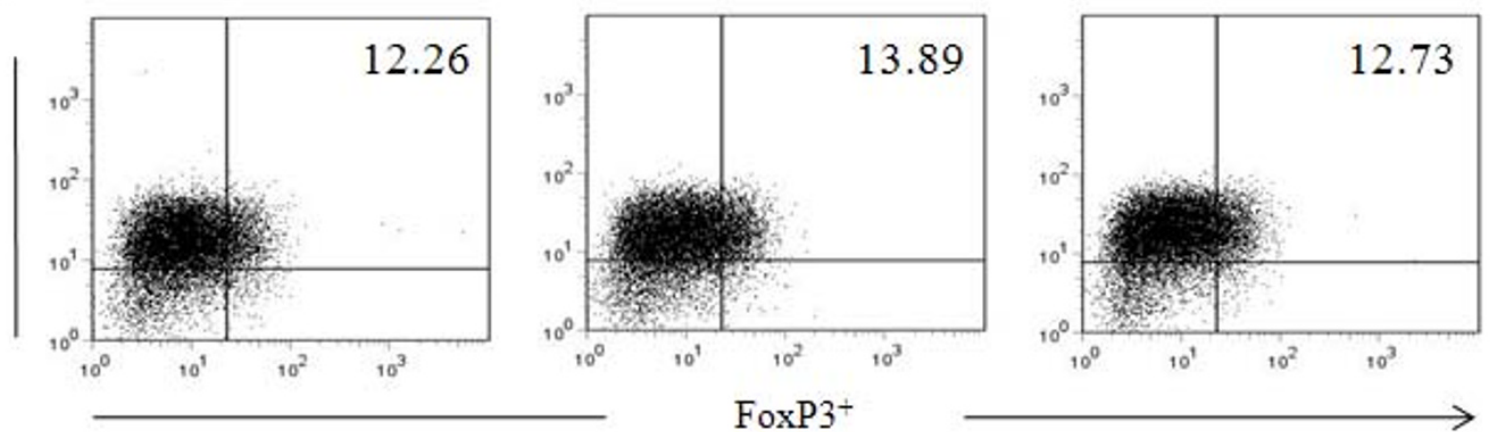

Figure 2 The number of Tregs increased when co-cultured with DCs and concomitantly treated with resistin. $C D 4^{+} T$ cells or $C D 4^{+} C D 25^{-} T$ cells and DCs were co-cultured with $500 \mathrm{ng} / \mathrm{ml}$ of resistin for 4 days. The cells were then incubated with anti-human CD2 and CD3 antibodies for an additional 3 days. (A) At the end of the incubation period, total RNA was isolated and subjected to RT-PCR to measure mRNA expression of CTLA-4, FoxP3 and TGF- $\beta$. (B) After the staining of the cells with anti-human CD25-APC and -FoxP3-PE antibodies, CD25+FoxP3+ Tregs were analyzed by flow cytometry. (C) After the staining with anti-human CD25-APC antibody, CD25+T cells were isolated using anti-APC magnetic beads. The isolated CD25+ T cells and CD4+ CD25- naïve T cells labeled with CFSE were co-cultured with DCs and stimulated with anti-human CD2 and CD3 antibodies for 5 days. Cell proliferation was measured by flow cytometry. The value in each panel indicates the percentage of CD25+ FoxP3+ Tregs. 
A

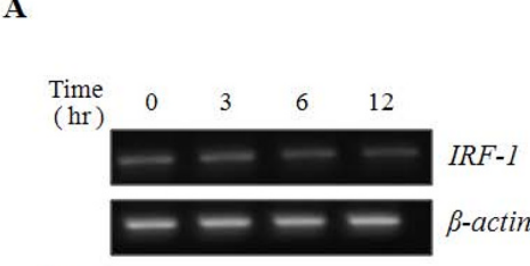

Dose

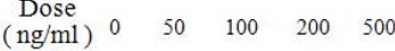

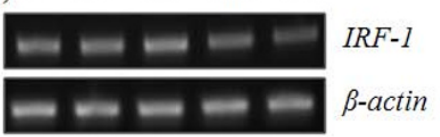

B

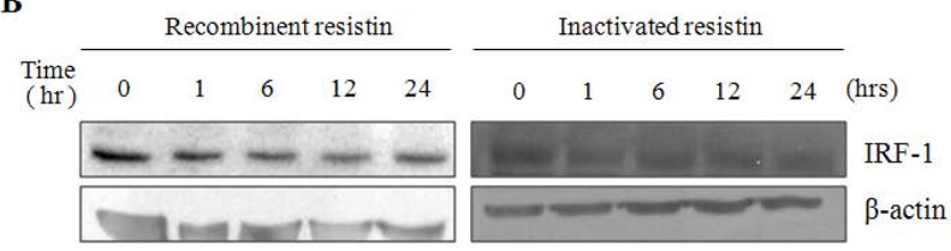

Dose

$\begin{array}{llllll}\underset{(\mathrm{ng} / \mathrm{ml})}{\text { Dose }} & 0 & 50 & 100 & 200 & 500\end{array}$
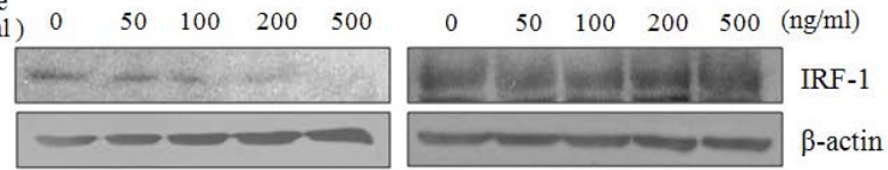

C

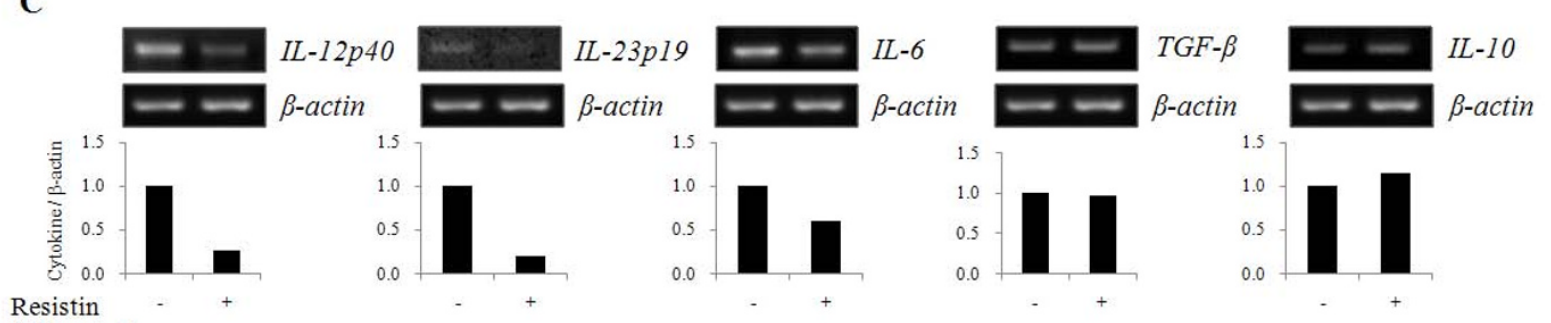

$(500 \mathrm{ng} / \mathrm{ml})$

Figure 3 Resistin suppressed the expression of IRF-1 and cytokines in DCs. The expression of IRF-1, in both (A) mRNA and (B) protein was determined in DCs treated with $500 \mathrm{ng} / \mathrm{ml}$ of resistin for the indicated time periods (upper panel in A and B) and treated with indicated amount for 24 hrs (bottom panel in A and B). The heat-inactivated resistin was used as a control. (C) The expression of IL-12p40, IL-23p19, IL-6, TGF- $\beta$ and IL-10 was measured by RT-PCR in DCs treated with $500 \mathrm{ng} / \mathrm{ml}$ of resistin for $12 \mathrm{hrs}$. The graphs show the intensity of each cytokine normalized to $\beta$-actin. Results are representative of three separate experiments with similar result.

ability to induce Tregs than mature DCs [19], we examined changes in the expressin of DC maturation markers (CD40, CD80, CD86 and HLA-DR) following resistin treatment (data not shown). We found no evidence for the involvement of resistin in the maturation of DCs, implying that the induction of Tregs is independent of DC maturation.

We further demonstrated that resistin suppressed the expression of IRF-1 and cytokines such as IL-6, IL-12p40 and IL-23p19 in DCs, suggesting the possibility that resistin-treated DCs are involved in the induction of Tregs. Indeed, IL- 6 enhances the conversion of Th17 cells to Tregs when combined with TGF- $\beta$, whereas it inhibits leukemia inhibitory factor (LIF), which is an essential factor for inducing FoxP3 expression in Tregs [20]. On the other hand, IL-12 is known as one of the most important cytokines for inducing differentiation of naïve $\mathrm{T}$ cells into Th1 cells [21]. IL-23p19 is well known as the important source to induce Th17 cells [13]. Therefore, these decrease of effect cytokines support the enhancing expansion of Tregs.

The down-regulation of IRF in our findings is supported by a previous study in IRF-1/- mice, which have high levels of $\mathrm{CD}^{+}{ }^{+} \mathrm{CD} 25^{+}$FoxP3 ${ }^{+}$Tregs, where the expression of FoxP3 was negatively regulated by IRF-1 [22]. We found that the expression of FoxP3 and CTLA-4 increased in parallel with the suppressive effect of Tregs when $\mathrm{CD}^{+} \mathrm{T}$ cells were co-cultured with $\mathrm{DCs}$ in the presence of resistin.

It has been shown that suppressors of cytokine signaling (SOCS) 3-deficient DCs, together with impaired production of cytokines (IL-12, IFN- $\gamma$ and IL-6) and costimulatory molecules (CD40 and CD86), preferentially induce the expansion of Tregs [23]. Our results also suggest that resistin decreases the production of SOCS3 in DCs (data not shown). Tregs can be induced by soluble factors, including TGF- $\beta$, IL10 and IL-2. TGF- $\beta$, in particular, suppresses inflammatory activity and promotes differentiation of Tregs [5]. Accordingly, we examined the source of TGF- $\beta$ that provoked the expansion of Tregs. We found that major source of TGF- $\beta$ required for the induction of Tregs was CD4+ $\mathrm{T}$ cells co-cultured with DCs in the presence of resistin, and not DCs themselves treated with resistin. It is to note that the treatment with TGF- $\beta$ or supernatant from any culture condition aforementioned had no impact on the expansion of Tregs (data not shown). Therefore it is most likely that in addition to TGF- $\beta$ produced from co-culture of $\mathrm{CD}^{+} \mathrm{T}$ cells and 
A

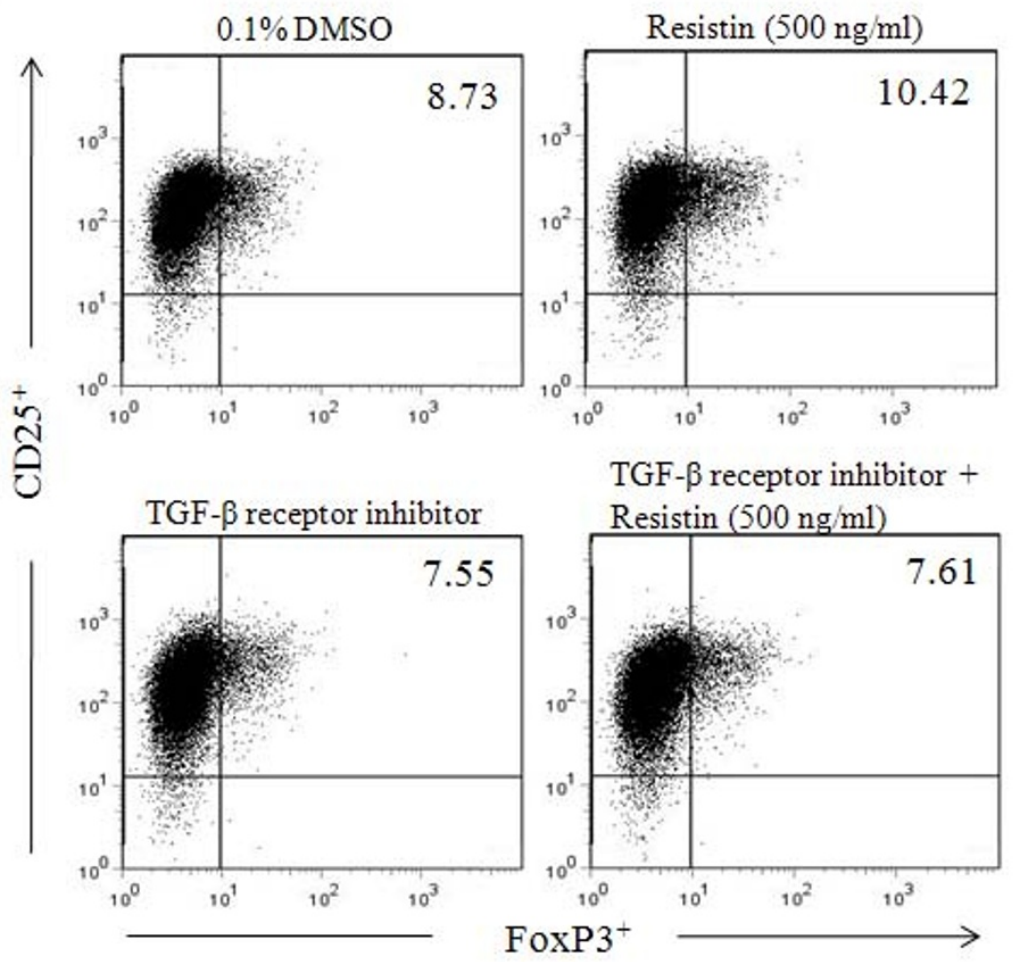

B

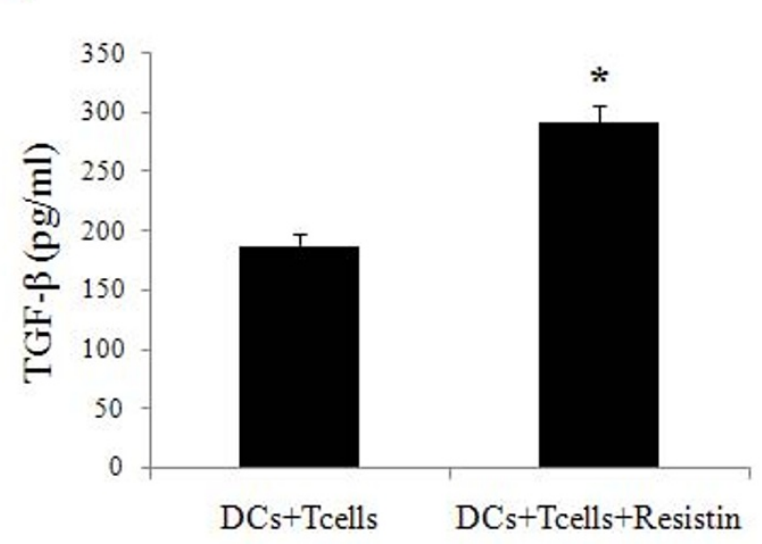

C

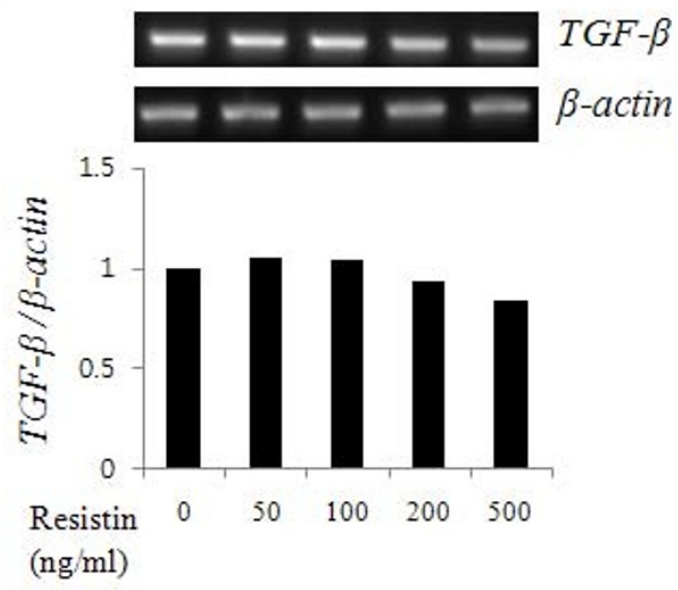

Figure 4 TGF- $\beta$ secreted by $C D 4+C D 25^{+}$FoxP3 ${ }^{+}$Tregs, but not by DCs, induces the expansion of Tregs. CD4+ $T$ cells were pre-treated with inhibitor for TGF- $\beta$ receptor for $1 \mathrm{hr}$ and co-cultured with DCs, followed by resistin treatment for 4 days. Anti-human CD2 and CD3 antibodies were then added to the cells for an additional 3 days. (A) CD25+FoxP3+Tregs were measured by flow cytometry. (B) TGF- $\beta$ production in the supernatant was measured by ELISA. (C) DCs were treated with various concentrations $(0,50,100,200$ and $500 \mathrm{ng} / \mathrm{ml})$ of resistin for 6 hrs and then TGF- $\beta$ mRNA expression was measured by RT-PCR. ${ }^{*} P<0.05$. The value in each panel indicates the percentage of CD25+FoxP3+Tregs. The results represent the mean \pm standard deviation from three separate experiments. 
DCs in the presence of resistin, cell to-cell contact is critically required for the induction of Tregs.

\section{Conclusions}

We have shown that resistin induces the expansion of regulatory $\mathrm{T}$ cells through regulating the expression of IRF-1 and its target cytokines, IL-6, IL-23p19 and IL12 p40 in human monocyte-derived dendritic cells.

\section{Additional material}

Additional file 1 Resistin-treated DCs quantitatively enhance the expansion of $\mathrm{CD}^{+}{ }^{+} \mathrm{CD} 25^{+}$FoxP3 ${ }^{+}$Tregs. CD4+ $\mathrm{T}$ cells and $\mathrm{DCs}$ were $\mathrm{CO}$ cultured with 0,50 or $100 \mathrm{ng} / \mathrm{ml}$ of resistin for 4 days. The cells were then incubated with anti-human CD2 and CD3 antibodies for an additional 3 days. After the staining of the cells with anti-human CD25-APC and FoxP3PE antibodies, CD25+ FoxP3+ Tregs were analyzed by using flow cytometry. The quantitative frequency of $\mathrm{CD} 25+$ FoxP3 + Tregs was plotted with five independent experiments. ${ }^{*}$ indicates significant difference at $P<0.05$ compared to no resistin treated group.

\section{Abbreviations}

BSA: bovine serum albumin; CFSE: carboxyfluorescein succinimidyl ester; CTLA: cytotoxic T-lymphocyte antigen; DCs: dendritic cells; FBS: fetal bovine serum; FoxP3: forkhead box P3; GM-CSF: granulocyte macrophage colony-stimulating factor; HRP: horseradish peroxidase; IL: interleukin; IRF: interferon regulatory factor; PBMC: peripheral blood mononuclear cells; PBS: phosphate buffered saline; PI: propidium iodide; SOCS: suppressors of cytokine signaling; TBST: Trisbuffered saline Tween-20; TGF: transforming growth factor- $\beta$; TMB: 3,3,5,5'tetramethylbenzidine dihydrochloride; TNF: tumor necrosis factor; Tregs: regulatory T cells; nTregs: natural Tregs; iTregs: inducible Tregs.

\section{Authors' contributions}

$\mathrm{CHY}$ and SHH conceived of and designed the study. YMS, SMA and GRK performed most RT-PCR, western blot and flow cytometry analyses. YMS drafted the manuscript. YSM and SHK advised designing the current experiment and editing the manuscript. YMP, WKL and TSM participated in the statistical analysis, its coordination and discussion of the manuscript. All authors have read and approved the final manuscript.

\section{Acknowledgements}

This study was supported by grants from the Biogreen 21 program (2008-0401 034054), Rural Development Administration, and from the Expansion of Nuclear R\&D Infrastructure Program through the Korea Science and Engineering Foundation (2008-01571) funded by the Korean Ministry of Education, Science and Technology, Republic of Korea. Authors would like to thank the National Instrumentation Center for Environmental Management (NICEM) and the Center for Agricultural Biomaterials (CAB), Seoul National University, Republic of Korea for supporting experimental facilities.

\section{Author Details}

1Protein Engineering and Comparative Immunology, Department of Agricultural Biotechnology and Research Institute for Agriculture and Life Sciences, Seoul National University, 599 Gwanak-ro, Gwanak-gu, Seoul 151-921, Republic of Korea, 2Molecular Biology, Department of Animal Science and Biotechnology, Jinju National University, Jinju 660-758, Republic of Korea, ${ }_{3}^{3}$ Animal Cell Physiology, Department of Biology, Kyung Hee University, Seoul 130-701, Republic of Korea, ${ }^{4}$ Department of Microbiology and Immunology and National Research Laboratory of Dendritic Cell Differentiation and Regulation, Medical Research Institute, Pusan National University, College of Medicine, Busan, Republic of Korea, ${ }^{5}$ Center for Advanced Medical Education by BK21 project, College of Medicine, Inha University, Incheon 402-751, Republic of Korea, ${ }^{6}$ National Research Foundation of Korea, Daejeon 305-350, Republic of Korea and ${ }^{7}$ Department of Oral Microbiology \& Immunology, Dental Research Institute, and BK21 Program, School of Dentistry, Seoul National University, Seoul 110-749, Republic of Korea
Received: 12 October 2009 Accepted: 30 June 2010

Published: 30 June 2010

\section{References}

1. Steppan CM, Bailey ST, Bhat S, Brown EJ, Banerjee RR, Wright CM, Patel HR, Ahima RS, Lazar MA: The hormone resistin links obesity to diabetes. Nature 2001, 409:307-12.

2. Bokarewa M, Nagaev I, Dahlberg L, Smith U, Tarkowski T: Resistin, an adipokine with potent proinflammatory properties. J Immuno/ 2005, 174:5789-95.

3. Silswal N, Singh AK, Aruna B, Mukhopadhyay S, Ghosh S, Ehtesham NZ Human resistin stimulates the pro-inflammatory cytokines TNF- $a$ and IL-12 in macrophages by NF-KB-dependent pathway. Biochem Biophys Res Commun 2005, 334:1092-101.

4. Wing $K$, Onishi Y, Prieto-Martin P, Yamaguchi T, Miyara M, Fehervari Z, Nomura T, Sakaguchi S: CTLA-4 control over FoxP3+ regulatory T cell function. Science 2008, 322:271-5.

5. Wan YY, Flavell RA: TGF- $\beta$ and regulatory T cell in immunity and autoimmunity. J Clin Immunol 2008, 28:647-59.

6. Horwitz DA, Zheng SG, Gray JD: Natural and TGF- $\beta$-induced Foxp3+ $\mathrm{CD} 4+\mathrm{CD} 25+$ regulatory T cells are not mirror images of each other. Trends Immunol 2008, 29:429-35.

7. Khattar M, Chen W, Stepkowski SM: Expanding and converting regulatory T cells: a horizon for immunotherapy. Arch Immunol Ther Exp 2009, 57:199-204

8. Jang MS, Son YM, Kim GR, Lee YJ, Lee WK, Cha SH, Han SH, Yun CH: Synergistic production of interleukin-23 by dendritic cells derived from cord blood in response to costimulation with LPS and IL-12. J Leukoc Biol 2009, 86:691-9.

9. Luo X, Tarbell KV, Yang H, Pothoven K, Bailey S, Ding R, Steinman RM, Suthanthiran M: Dendritic cells with TGF- $\beta 1$ differentiate naive CD4+ CD25+ T cells into islet-protective Foxp3+ regulatory T cells. Proc Natl Acad Sci USA 2007, 104:2821-6.

10. Gabriele L, Fragale A, Borghi P, Sestili P, Stellacci E, Venditti M, Schiavoni G, Sanchez M, Belardelli F, Battistini A: IRF-1 deficiency skews the differentiation of dendritic cells toward plasmacytoid and tolerogenic features. J Leukoc Biol 2006, 80:1500-11.

11. Son YM, Ahn SM, Jang MS, Moon YS, Kim SH, Cho KK, Han SH, Yun CH: Immunomodulatory effect of resistin in human dendritic cells stimulated with lipoteichoic acid from Staphylococcus aureus. Biochem Biophys Res Commun 2008, 376:599-604.

12. Belkaid Y, Oldenhove G: Tuning microenvironments: Induction of regulatory T cells by dendritic cells. Immunity 2008, 29:362-71.

13. Diveu C, McGeachy MJ, Cua DJ: Cytokines that regulate autoimmunity. Curr Opin Immunol 2008, 20:663-8.

14. Son YG, Zan LS, Wang HB, Guo HF, Yang DP, Zhao XL, Gui LS: Insulin Inhibits the Expression of Adiponectin and AdipoR2 mRNA in Cultured Bovine Adipocytes. Asian-Aust J Anim Sci 2009, 22:1429-1436.

15. Cohen G, llic D, Raupachova J, Horl WH: Resistin inhibits essential functions of polymorphonuclear leukocytes. J Immunol 2008, 181:3761-8.

16. Reilly MP, Lehrke M, Wolfe ML, Rohatgi A, Lazar MA, Rader DJ: Resistin is an inflammatory marker of atherosclerosis in humans. Circulation 2005, 111:932-9.

17. Rutella S, Danese S, Leone G: Tolerogenic dendritic cells: cytokine modulation comes of age. Blood 2006, 108:1435-40.

18. Terme M, Chaput N, Combadiere B, Ma A, Ohteki T, Zitvogel L: Regulatory T cells control dendritic cell/NK cell cross-talk in lymph nodes at the steady state by inhibiting CD4+ self-reactive T cells. J Immunol 2008, 180:4679-86.

19. Mahnke K, Johnson TS, Ring S, Enk AH: Tolerogenic dendritic cells and regulatory T cells: A two-way relationship. J Dermatol Sci 2007, 46:159-67.

20. Gao W, Thompson T, Zhou Q, Putheti P, Fahmy TM, Strom TB, Metcalfe SM: Treg versus Th17 lymphocyte lineages are cross-regulated by LIF versus IL-6. Cell Cycle 2009, 8:1444-50.

21. Wada Y, Hisamatsu T, Kamada N, Okamoto S, Hibi T: Retinoic acid contributes to the induction of IL-12-hypoproducing dendritic cells. Inflamm Bowel Dis 2009, 15:1548-56.

22. Fragale A, Gabriele L, Stellacci E, Borghi P, Perrotti E, Ilari R, Lanciotti A, Remoli AL, Venditti M, Belardelli F, Battistini A: IFN Regulatory Factor-1 
Negatively Regulates CD4+ CD25+ Regulatory T Cell Differentiation by Repressing Foxp3 Expression. J Immunol 2008, 181:1673-82.

23. Matsumura Y, Kobayashi T, Ichiyama K, Yoshida R, Hashimoto M, Takimoto T, Tanaka K, Chinen T, Shichita T, Wyss-Coray T, Sato K, Yoshimura A: Selective expansion of Foxp3-positive regulatory $T$ cells and immunosuppression by suppressors of cytokine signaling 3-deficient dendritic cells. J/mmuno/ 2007, 179:2170-9.

doi: 10.1186/1471-2172-11-33

Cite this article as: Son et al., Resistin enhances the expansion of regulatory T cells through modulation of dendritic cells BMC Immunology 2010, 11:33

Submit your next manuscript to BioMed Central and take full advantage of:

- Convenient online submission

- Thorough peer review

- No space constraints or color figure charges

- Immediate publication on acceptance

- Inclusion in PubMed, CAS, Scopus and Google Scholar

- Research which is freely available for redistribution

Submit your manuscript at www.biomedcentral.com/submit
() BioMed Central 